\title{
Beyond capital controls: regulation of foreign currency derivatives markets in the Republic of Korea and Brazil after the global financial crisis
}

\author{
Daniela Magalhães Prates and Barbara Fritz
}

ABSTRACT

\begin{abstract}
Within the management of capital flows, some emerging economies have been facing economic policy dilemmas after the global financial crisis, related to financial instrument operations, in a context of abundant liquidity in the advanced economies. However, neither the academic literature nor the financial institutions have paid sufficient attention to foreign currency (FX) derivatives regulation in emerging economies. This paper analyses the measures adopted by Brazil and the Republic of Korea. We find, first, that the breadth of regulation concerning FX derivatives operations depends on the actors involved and the type of contract used. Second, effective domestic institutions are needed to formulate and implement regulations. Third, countries should not limit their policy space through multilateral or bilateral agreements, and leave space for domestic financial regulation.
\end{abstract}

KEYWORDS

JEL CLASSIFICATION

AUTHORS
Capital movements, foreign exchange control, derivative securities, foreign exchange, financial crisis, Republic of Korea, Brazil

F36, F41

Daniela Magalhães Prates is associate professor at the Institute of Economics of the State University of Campinas, Brazil.prates@unicamp.br

Barbara Fritz is full professor at the Institute for Latin American Studies of the Freie Universität Berlin, Germany. Barbara.Fritz@fu-berlin.de 


\section{I}

\section{Introduction}

Emerging economies have been coping with the problems of success. ${ }^{1}$ Not only have they boasted higher employment and growth rates than member countries of the Organisation for Economic Cooperation and Development (OECD), but they also have recovered rapidly from the financial crisis sparked by the 2008 Lehman Brothers default. Consequently, since mid-2009, emerging economies have seen a new boom in capital inflows, albeit a highly unstable one. Many governments have become increasingly concerned about the downsides of such inflows. They perceive dependence on highly volatile capital flows as a threat to short-term financial stability and, more generally, to their domestic economic policy space.

At the same time, the debate on capital controls, long discarded as anachronistic, has returned to the political and academic agenda with a vengeance (Gallagher, Griffith-Jones and Ocampo, 2012; Jeanne, Subramanian and Williamson, 2012; Fritz and Magalhães Prates, 2014). Even the International Monetary Fund (IMF), which was long hostile to any kind of capital control regime, is engaging in a new debate on capital flow management (IMF, 2012b). However, this debate has caught international financial institutions, and much of academia, ill prepared. As Rodrik (2010, p. 2) states, "we currently do not know much about designing capital control regimes. The taboo that has [been] attached to capital controls has discouraged practical, policy-oriented work that would help to manage capital flows directly."

Besides the management of capital flows (spot settlement), some emerging economies have also faced economic policy dilemmas related to foreign (non-resident) and domestic (resident) FX derivatives operations (forward settlement). In an environment of abundant liquidity and historically low interest rates in advanced economies, foreign investors searching for short-term yield, as well as domestic agents, often obtain huge profits from the interest rate differentials between advanced and emerging economies. Yet the regulation of FX derivatives in emerging economies has not received due attention, whether in the academic

\footnotetext{
1 "Emerging economies" are defined herein as developing countries that have engaged in financial globalization. We are thus not employing the International Monetary Fund (IMF) definition, which classifies the Republic of Korea as a newly advanced economy.
}

literature or within international financial institutions, though it might prove crucial for emerging economies with a high degree of financial openness and liquidity as well as for deep FX derivatives markets, such as Brazil and the Republic of Korea.

As Mihaljek and Packer (2010, p. 51) point out, Brazil and the Republic of Korea have the largest FX derivatives markets among emerging economies. This feature, combined with a hands-off approach to capital inflows, seemed to reinforce the contagion effect of the global financial crisis on the currencies and financial markets of both countries, despite their current account surpluses until 2007 and their huge international reserves (Prates and Cintra, 2010).

Brazil and the Republic of Korea (like other emerging economies) have learned hard lessons from the global crisis, which showed that reserve accumulation could not cushion them against the adverse effects of volatile capital flows and speculative operations in the FX derivatives markets. Since 2009, both countries have resorted to capital controls and prudential financial regulation to deal with the new boom of capital flows to emerging economies. ${ }^{2}$ These and other regulatory tools are also being used to curb the FX derivatives transactions of non-residents and/or resident agents.

This paper analyses the approaches adopted by Brazil and the Republic of Korea to FX derivatives regulation in the wake of the global financial crisis. Regulation of operations in domestic FX derivatives markets is difficult to assess by econometric methods, as the analysis has to deal with the overlap and interdependency of factors in very short time periods, including the following: (i) frequent external shocks, given the unstable global environment and the high volatility of international capital flows; (ii) very short time periods; (iii) macroeconomic policy shifts, especially in terms of monetary and foreign exchange policies, and (iv) frequent regulatory changes at the domestic level. Our analysis therefore incorporates qualitative methods and descriptive statistical analysis.

In contrast to empirical assessments, we focus here on the specificity of FX derivatives regulation in Brazil

\footnotetext{
2 Besides Brazil and the Republic of Korea, the main recipients of capital inflows in the post-crisis boom of capital flows have been South Africa, Peru, Thailand, Indonesia and Turkey. For more details, see IMF (2011a).
} 
and the Republic of Korea. Our hypothesis is that this kind of regulation is distinct from capital controls and prudential financial regulation, which have to be adjusted in keeping with the country-specific institutional framework in order to cover this class of financial transaction and to encompass both non-resident and resident agents.

The paper seeks to contribute to the debate on financial regulation in response to the global crisis. While there is a growing consensus on the need for a more systemic approach to macroeconomic, monetary and financial policies (Blanchard, Dell' Ariccia and Mauro, 2010; Eichengreen and others, 2011), as opposed to one that prioritizes price-level stabilization alone, the debate on the regulation of international capital flows - in particular FX derivatives in emerging economies - is far from consolidated, both in theoretical terms and with regard to economic policy recommendations.
In section II, based on a review of typologies of capital flow regulation, we establish a broad approach to financial regulation. This enables us to take in countryspecific regulatory approaches. In emerging economies characterized by a high degree of financial openness and sophisticated domestic financial markets, such as our cases, these markets and cross-border flows are deeply intertwined. We thus argue that the analytical division, generally adopted in the literature, between domestic and external financial regulation, is no longer useful or even possible. In this setting, prudential financial regulation, capital controls and other regulatory measures (such as the regulation of FX derivatives markets) should be seen as an essential part of the financial regulatory toolkit. In section III, we analyse the experiences of the Republic of Korea and Brazil. Some general conclusions from these case studies are set out in section IV.

\section{II}

\section{A broad approach to financial regulation}

The academic literature on the regulation of capital flows by emerging economies - that is, external financial regulation — has flourished since the 1990s and gained further momentum after the global financial crisis, resulting in different typologies.

Given the volume and volatility of these flows and their potentially damaging consequences for emerging economies, IMF has effected a clear shift in its official position on the evaluation of capital controls (IMF, 2010, 2011a and 2012b; Ostry and others, 2010 and 2011a), which resulted in a new institutional view endorsed by the Fund (IMF, 2011a and 2012b). In these recent papers, the set of tools designed to influence capital inflows is called "capital flows management measures", defined as the sum of the measures established to slow exchange rate appreciation or divert these flows to other countries. It comprises measures that distinguish between residency statuses and between currency denominations, as well as other regulations such as minimum holding periods and taxes on specific investments that are typically applied in the non-financial sector (IMF, 2011a).

In academia, the discussion started earlier. In chronological order, Epstein, Grabel and Jomo (2004) use the term "capital management techniques" for two complementary types of financial regulations that affect capital flows and that often overlap. These are the policies that govern international private capital flows, called "capital controls", and enforce the prudential management of domestic financial institutions. Their definition takes into account the fact that some prudential financial regulation instruments function in practice as capital controls, while others contribute to reducing systemic financial risks. Ocampo (2012) and Gallagher, Griffith-Jones and Ocampo (2012) prefer the term "capital account regulations" (CARS) to underscore the fact that these regulations on capital flows belong to the broader family of financial regulations and should encompass not only inflows, but also outflows and price-based and quantity-based instruments. Priewe (2011) puts forward the concept of "capital account management," which encompasses all the forms by which authorities could have (in)direct influence on capital flows and capital accounts, to wit: sovereign monetary and fiscal policy, exchange rate management, domestic financial sector regulations, regulations related to foreign direct investment (FDI), direct capital controls and international rules, and coordination intervention to stabilize exchange rates. 
Despite conceptual differences, especially between IMF and other approaches, all theorists acknowledge four key precepts. ${ }^{3}$ First, the regulation of capital flows needs to encompass multi-faceted policies — capital controls and prudential regulations - since no single measure can achieve diverse objectives. Second, a strict bifurcation between these policies often cannot be maintained in practice (Epstein, Grabel and Jomo, 2004; Ocampo, 2012). Third, there is often a great deal of synergy and overlap between these measures. In particular, Epstein, Grabel and Jomo (2004, p. 6) point out that "the effectiveness of any single management technique magnifies the effectiveness of other techniques and enhances the efficacy of the entire regime of capital management. For example, certain prudential financial regulations magnify the effectiveness of capital controls (and vice versa). In this case, the stabilizing aspect of prudential regulation reduces the need for the most stringent form of capital control. Thus, a programme of complementary capital management techniques reduces the necessary severity of any one technique and magnifies the effectiveness of the regime of financial control." Finally, there are also feedback loops between these two regulations (prudential financial regulations and capital controls) and macroeconomic policy.

Moreover, in emerging economies with a high degree of financial openness and sophisticated domestic financial markets, these markets and cross-border flows are deeply intertwined. Consequently, the traditional analytical division (generally adopted in the literature) between

3 For a critical analysis of the new IMF approach, see Fritz and Magalhães Prates (2014), and Gallagher (2012). domestic and external financial regulation is no longer useful or even possible. Therefore, financial regulation in emerging economies with these features should be considered in a broader sense, without separating its internal and external dimensions. Prudential financial regulations, capital controls and other regulatory measures (such as the regulation of derivatives markets) should be seen as an essential part of the financial regulatory toolkit governing residents and non-residents, as well as financial and non-financial agents, with respect to their portfolio decisions in foreign and domestic currency, and in both spot and derivatives markets.

This toolkit should be country-specific, shaped by local context in terms of the degree of financial openness, the financial system's institutional framework and the country's policy goals for regulation. In the case of emerging economies, the most important goals are to reduce risks and increase policy space in the effort to control key macroeconomic prices, such as the exchange rate and the interest rate, particularly to enable the pursuit of countercyclical policies that mitigate booms and busts of capital flows and the risk appetite of global investors. There are important feedbacks between these two goals. For instance, currency appreciation stimulates speculative positions in FX derivatives, threatening financial stability. Therefore, the ability to maintain the exchange rate at a competitive level (secondary goal) contributes to this stability (primary goal).

As each regulatory tool is also specific in terms of the range of agents and markets that it can reach (see table 1), each country's regulatory toolkit may encompass a number of regulations, depending on its institutional specificities and policy goals. It is therefore important to define each type of regulatory tool clearly.

Financial regulation toolkit

\begin{tabular}{lccc}
\hline \multirow{2}{*}{ Regulation } & \multicolumn{2}{c}{ Agents } & \multicolumn{2}{c}{$\begin{array}{c}\text { Market } \\
\text { (spot or derivatives) }\end{array}$} \\
\cline { 2 - 4 } & Financial or non-financial & Resident or non-resident & Both \\
Prudential regulation & Financial institutions & Resident & Derivatives \\
FX derivatives regulation & Both & Both & Spot \\
Capital controls & & & Non-resident \\
$\quad$ Portfolio investments and FDI & Both & Resident & Spot \\
\hline
\end{tabular}

Source: Prepared by the authors.

Note: FDI: Foreign direct investment. 
Prudential financial regulations refer to policies such as capital-adequacy standards, reporting requirements or restrictions on the ability and terms under which domestic financial institutions can provide capital to certain types of project. They may also include prudential rules on currency mismatching of balance sheets, or restrictions on issuing certain types of derivative or forward contract (Epstein, Grabel and Jomo, 2004). These regulations only affect the asset and liability positions of resident financial institutions.

As for capital controls, there is no unique, generally accepted legal definition. We thus adhere to the broadest functional definition as proposed by Neely (1999), according to which these controls refer to measures that manage the volume, composition or allocation of international private capital flows. ${ }^{4}$ Capital controls can target inflows or outflows, and they generally concern particular flows (such as portfolio investment, based on their perceived risks and opportunities). Moreover, capital controls can be tax-based or quantitative. Financial taxes or reserve requirements against certain types of investment are examples of tax-based controls. Quantitative capital controls involve outright bans on certain investments (for example, the purchase of equities by foreign investors), restrictions or quotas, or license requirements (Epstein, Grabel and Jomo, 2004). In other words, capital controls are a range of financial regulation tools that manage cross-border flows (both inflows

\footnotetext{
${ }^{4}$ Ostry and others (2011a, p. 11) admit that there is no unique definition of capital controls, but stick to a juridical definition presented by the Organisation for Economic Cooperation and Development (OECD) in its OECD Code for Liberalization of Capital Movements (2009), which considers capital controls to be subject to liberalization obligations only if they discriminate between residents and non-residents. Later IMF papers on this subject also adopt this definition. Herein lies one of the problems with the new IMF approach. For the sake of nondiscrimination, capital controls defined in this manner should be applied only as a means of last resort. IMF has introduced a hierarchy of measures instead of focusing on the adequacy and efficiency of the regulations at hand.
}

and outflows) associated with both foreign investors and resident companies and banks. Unlike prudential financial regulations, they can influence portfolio decisions taken by resident non-financial institutions and non-resident agents.

In addition to prudential financial measures and capital controls, a third kind of regulation may be needed to curb financial risks and increase policy space in emerging economies with open and sophisticated FX derivatives markets, depending on the institutional features of these markets. On the one hand, prudential financial regulation may not be sufficient to reach FX derivatives operations, as it only affects financial institutions' balance sheets; FX derivatives operations carried out by non-resident investors and non-financial resident agents are thus outside the scope of this class of regulation. On the other hand, capital controls influence cross-border transactions alone and, hence, do not cover FX derivatives operations in the domestic market. Even for an operation carried out by foreign investors, capital controls are not the most suitable and effective type of regulation, since they would have only a small impact in the case of, say, a capital inflow related to paying for the cost of a derivative operation, like margin requirements on futures contracts. One important characteristic of financial derivatives as a whole is their high degree of leverage, to the extent that they require only a margin requirement or the payment of a premium to be carried out. This specific feature, in turn, makes FX derivatives a privileged instrument for currency speculation and profiting from interest rate differentials. Furthermore, these inflows may not even take place: in emerging economies with open financial markets, foreign investors typically have investments in other assets that they could settle and transfer to meet this cost. This third class of regulation will herein be referred to as foreign exchange derivatives regulations, focusing on regulating resident and non-resident operations with this forward settlement instrument in the domestic market (see table 1).

\section{III}

\section{Case studies}

Since 2008, most advanced economies have been marked by financial turmoil and sharp recessions or low growth, while most emerging economies and some developing countries have been faring much better in financial and economic terms (Ocampo, 2012; Canuto and Giugale, 2010; Canuto and Leipziger, 2012).

In response to these conditions, the advanced economies implemented quantitative easing $(\mathrm{QE})$ policies, 
generating abundant liquidity and low interest rates and triggering a new boom in capital flows to emerging economies since the second quarter of 2009. This new boom - the fourth in the post-Bretton Woods era- has thus been driven by post-crisis circumstances. These flows lost some momentum after May 2013, when the Federal Reserve of the United States of America indicated that it might begin tapering its QE policy towards the end of the calendar year. Nevertheless, we assume that emerging markets will experience an extended period of high capital inflows (Akyüz, 2011; BIs, 2010; Canuto and Leipziger, 2012).

As before the crisis, the currencies and assets of several emerging countries have once again become the target of carry trade activities — due to interest rate differentials - and other capital flows. The resulting combination of high growth rates, accelerating inflation (also associated with a renewed commodity price boom), excessive currency appreciation and/or assetprice overshooting has presented emerging economies with policy dilemmas (Akyüz, 2011; BIS, 2010). In this scenario, the adoption of restrictive monetary policy would help to contain growth and inflationary pressures, but it would encourage further capital inflows, which, in turn, would foster an asset price boom and exchange rate misalignment, thereby aggravating the risk of future sudden stops and subsequent financial crises. To deal with these dilemmas, many emerging economies have turned to capital controls and prudential financial regulations. In a departure from the pre-crisis context, many of these countries are now unwilling to adopt a hands-off approach to capital inflows.

However, country experiences both prior to the global financial crisis (Ariyoshi and others, 2000; Herr and Priewe, 2006; Magud, Reinhart and Rogoff, 2011) and after it (Klein, 2012; IMF, 2011a; Fritz and Magalhães Prates, 2014; Baumann and Gallagher, 2012 and 2013) indicate that designing the financial regulatory toolkit is a highly complex process, as it is shaped by a set of macroeconomic, institutional and structural factors, such as the degree of financial openness, the composition of capital flows, the features of financial and currency markets, and the policy goals at hand.

The experiences of Brazil and the Republic of Korea, the two case studies presented in this paper, exemplify this complexity. These countries pursued very similar strategies in managing capital flows in 2003-2007, with an overinvestment in costly reserve accumulation and underinvestment in capital account management policies (Rodrik, 2006, p. 12). Like other emerging economies, however, policymakers in Brazil and the Republic of Korea learned lessons from the global financial crisis, seeing that this strategy was not able to cushion them against the harmful effects of excessive risk-taking by domestic financial institutions or of currency overappreciation, caused by capital flows and FX derivatives operations.

In the face of the renewed risk appetite of global investors for emerging economies' assets and currencies since 2009, these two countries have adopted a number of regulatory measures to address policy dilemmas and avoid the reemergence of these imbalances. Both were forced to adopt specific regulations targeting FX derivatives operations, in addition to regulations aimed at curbing capital flows, given how they influence the exchange rate trend and the financial situation of banks and corporations in both economies. The following two subsections detail the regulations implemented by Brazil and the Republic of Korea to curb risk-taking strategies through FX derivatives operations, with variants in each country due to the different institutional features of their FX derivatives markets. ${ }^{5}$

\section{Republic of Korea}

After the crisis of 1997, the Government of the Republic of Korea decided to increase the country's financial openness. As Kim and Yong Yang (2010) point out, most capital flow restrictions were dismantled, and, as also occurred in Brazil, capital inflows and outflows became market determined. During the capital flow boom between 2003 and 2007, the Republic of Korea initiated a process of reserve accumulation and steadily relaxed outward investment controls to stem appreciation pressures; this resulted in the elimination of most controls by 2007 (Baba and Kokenyne, 2011).

The resumption of inflows following the global financial crisis was led by portfolio flows into debt and equity markets, and driven by factors both external (the post-crisis circumstances) and internal (the country's quick economic recovery and sound macroeconomic situation). Short-term bank debt, however, remained lower than in the pre-crisis period, thanks to the financial regulation strategy launched by Republic of Korea authorities after November 2009 to deal with the new boom in capital flows (see table 2). This strategy, in turn, had been shaped by the huge contagion effect exerted

\footnotetext{
5 Since the focus of our analysis is Fx derivatives operations, the regulation of capital flows is portrayed in broad strokes in this paper. For a detailed analysis of this regulation in Brazil and the Republic of Korea after the global financial crisis, see IMF (2011a) and Fritz and Magalhães Prates (2014).
} 
by the global financial crisis in the Republic of Korea banking system. ${ }^{6}$

As in the case of Brazil, the sharp devaluation of the currency of the Republic of Korea (the won) was associated with companies' FX derivatives operations. The overshooting of the won-dollar exchange rate (see figure 1) between August 2007 and October 2008 was the result of the relationship between FX derivatives operations carried out in the onshore over-the-counter (отC) derivative markets and the large short-term debt contracted by the country's banks. This link was related to two institutional features of the FX derivatives market in the Republic of Korea. First, in OTC derivatives markets, banks perform the role of the counterparty

6 In 2009, the Government initiated a US\$ 130 billion rescue plan to stabilize the domestic financial market, especially the foreign exchange market, because of banks' huge foreign currency liabilities (Prates and Cintra, 2010). of their clients. Second, gains or losses are settled in United States dollars (that is, they are deliverable), as is the case in most countries, though not in Brazil. Before the crisis, the banks sold "knock-in knock-out" (KIKO) foreign exchange options, an exotic оTC derivative for hedging against the appreciation of the local currency in relation to the dollar, to exporter companies (mainly shipbuilders). As Dodd (2009) explains, this option allowed firms to sell dollars at a fixed won-dollar exchange rate (which is the price of United States dollars) in the event that the exchange rate fluctuated within a range stipulated in the contract, providing a long position in the local currency. Companies' potential gains on the transactions (in case the won appreciated, as they were long in this currency) were capped or limited, while losses (in case the won depreciated) were not limited, but rather geared to occur at a faster rate (usually twice the rate) for a given change in the underlying exchange rate.

TABLE 2

Republic of Korea: financial regulation toolkit

\begin{tabular}{|c|c|c|}
\hline Date & Number and kind & Measure \\
\hline Nov. 2009 & 1 st PR & $\begin{array}{l}\text { - Higher foreign currency liquidity standards to reduce the maturity mismatch of banks' foreign } \\
\text { currency assets and liabilities and to improve the quality of their liquid assets. } \\
\text { - A } 125 \% \text { cap (relative to underlying export revenues) on forward foreign exchange contracts } \\
\text { between banks and exporters. }\end{array}$ \\
\hline June 2010 & 2nd PR & $\begin{array}{l}\text { - A ceiling on resident banks' FX derivatives contracts of no more than } 50 \% \text { and -in the case } \\
\text { of branches of foreign banks- of no more than } 250 \% \text { of their capital in the previous month. } \\
\text { - A limit on banks, allowing them to provide only } 100 \% \text { of underlying transactions for forward } \\
\text { contracts with exporters (previously } 125 \% \text { ). } \\
\text { - A stipulation that resident banks' FX loans and held-to-maturity securities (equal to or more than } \\
\text { one-year maturity) must be covered by at least } 100 \% \text { of FX borrowing with maturity of more } \\
\text { than one year. }\end{array}$ \\
\hline June 2010 & $1 \mathrm{st} \mathrm{CC}$ & $\begin{array}{l}\text { Limit on Fx financing for overseas use only, with some exceptions for small and } \\
\text { medium-sized manufacturers. }\end{array}$ \\
\hline Jan. 2010 & 2nd CC & $\begin{array}{l}\text { Reintroduction of a } 14 \% \text { withholding tax on non-residents' purchases of treasury and monetary } \\
\text { stabilization bonds, bringing the tax back in line with the tax on residents' bond purchases. Foreign } \\
\text { corporations and non-residents are subject to the withholding tax, but those based in countries that } \\
\text { have double taxation treaties with the Republic of Korea and official investors are exempt. }\end{array}$ \\
\hline June 2011 & $3 \mathrm{rd} P R$ & Limits on banks' FX derivatives tightened. \\
\hline Aug. 2011 & $3 \mathrm{rd} \mathrm{CC}$ & Levy on Fx liabilities. \\
\hline Nov. $2012^{\mathrm{a}}$ & 4th PR & Limits on banks' FX derivatives tightened. \\
\hline
\end{tabular}

Source: International Monetary Fund (IMF), "Recent Experiences in Managing Capital Inflows. Cross-Cutting Themes and Possible Policy Framework", 2011 [online] http://bit.ly/QSqrVQ; M. Pradhan and others, "Policy responses to capital flows in emerging markets", IMF Staff Discussion Notes, No. 11/10, Washington, D.C., International Monetary Fund, 2011; Bank of Korea [online] http://www.bok.or.kr/ eng/engMain.action; and Reuters.

Note: cC: Capital control; PR: Prudential regulation.

a Announcement date: measure effective since January 2013. 
FIGURE 1

Republic of Korea: nominal exchange rate and financial regulation measures (Won per dollar)

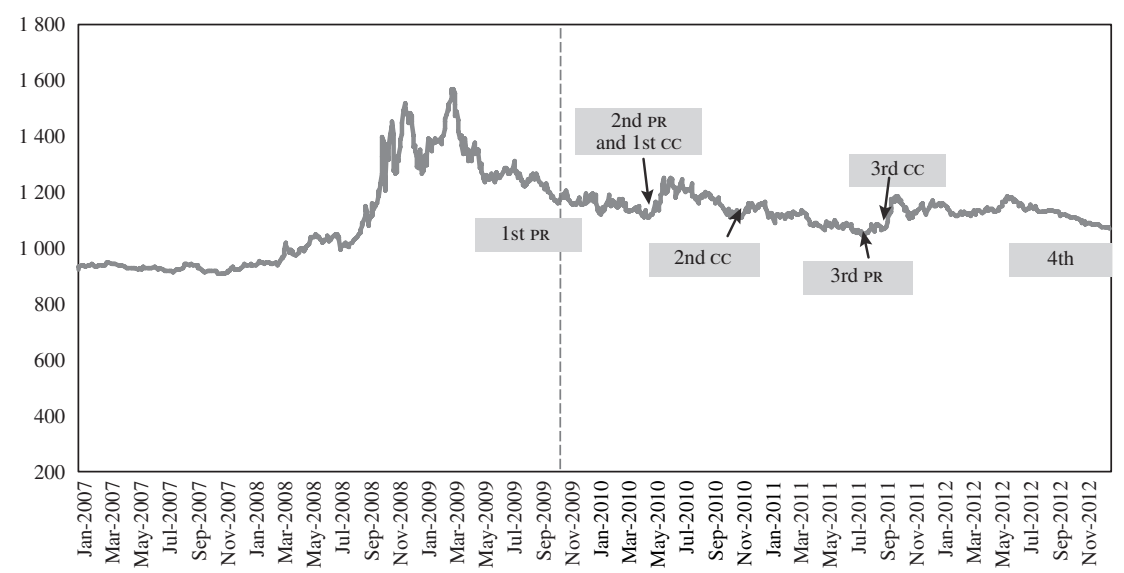

Source: Prepared by the authors, on the basis of information from Bloomberg.

Note: PR: Prudential regulation; CC: Capital control.

These companies began to hedge their foreign exchange exposure in 2004 and increased their hedging ratio in anticipation of continued won appreciation. Moreover, banks (mainly the local branches of foreign banks, which were only subject to risk management standards, not to liquidity ratios or other direct regulations applicable to Korean banks) engaged in interest rate arbitrage, borrowing dollars on a short-term basis, selling those dollars for won on the spot market, then buying certificates of deposit or other domestic bonds and selling the won forward for dollars. It was against this backdrop of strong capital inflows that authorities progressively liberalized capital outflows (Baba and Kokenyne, 2011; IMF, 2011a).

To make operations in the оTC derivatives market possible and profitable, national and foreign banks with local branches borrowed in United States dollars to sustain their positions in this market. With the outbreak of the crisis and the credit crunch in international financial markets, these banks were unable to roll over their maturing short-term external liabilities as global banks cut credit lines to shore up liquidity. National banks then started buying dollars to liquidate their external liabilities, thus exerting devaluating pressure on the won. This depreciation led to losses for companies that relied on the currency's appreciation and forced them to hand over the corresponding dollars, some of which had to be obtained on the spot foreign exchange market, to the banks. This put further depreciation pressure on the won. Around 520 small and medium-sized export companies that had purchased KIKO options lost an estimated US\$ 2 billion, landing them on the verge of insolvency. Several national banks suffered when their customers sued or became bankrupt (IMF, 2011a; Kim and Yong Yang, 2010; Dodd, 2009).

The contagion effect of the global financial crisis thus revealed the significant vulnerability of the banking system of the Republic of Korea to changes in global funding conditions, due to its high levels of short-term external debt and related FX derivatives, as well as the impact of these spot and derivatives operations on the exchange rate. The financial regulation toolkit adopted by the Government of the Republic of Korea since 2009 has therefore sought to reduce the financial risks and the exchange rate changes linked to capital flows and FX derivatives operations (see table 2).

Given that the main targets of the financial regulation were banks' spot and forward foreign exchange exposures, national authorities introduced a set of prudential financial regulatory measures after November 2009 (see table 2), with the goal of strengthening banks' foreign exchange liquidity management and limiting their shortterm debt and forward contracts to sustainable levels. The measures for reaching these FX forward positions indirectly aimed at reducing external borrowing by the banking sector, as had been the case before the crisis. National and foreign banks with local branches borrowed in United States dollars to sustain their positions in the OTC derivatives market. 
Therefore, prudential financial regulation measures, which only addressed banks' asset and liability positions in both the spot and forward markets (see table 2), helped to prevent external debt from returning to pre-crisis levels and contributed to limiting onshore FX derivatives operations. Both issues were closely linked with the banks' portfolio decisions. Hence, these measures aided in protecting the exchange rate from appreciation pressures deriving from banks' short-term external debt.

Since the adoption of these first prudential financial regulation measures, the won-dollar nominal exchange rate has been nominally stable, with the won appreciating only $0.9 \%$ (see figure 1). ${ }^{7}$ In the face of renewed appreciation pressures in the last quarter of 2012 due to Japan's ultra-expansionary monetary policy, Republic of Korea authorities tightened the limits on banks' FX derivatives in November 2012 (Jun and Nam, 2012; see table 2).

Some empirical studies point to the effectiveness of the regulatory toolkit of the Republic of Korea. According to Bruno and Shin (2013), the sensitivity of capital flows into the Republic of Korea to global conditions decreased in the period following the introduction of macroprudential policies in 2010. Baumann and Gallagher (2013) find that national controls had a statistically significant negative impact on exchange rate volatility. Similarly, Huh, An and Yang (2013) find that the Republic of Korea's macroprudential measures in the 2000s affected the maturity structure of the banks' foreign liability.

While prudential financial measures have been the main regulatory tool of choice for national policymakers, the Republic of Korea has also adopted capital controls to counter the undesirable effects of capital flows. In that regard, the main capital control measure was the withholding tax on foreign holdings of government bonds and central bank securities, bringing the tax back in line with the tax on residents' bond purchases. This price-based capital control was re-imposed in January

\footnotetext{
7 According to Pradhan and others (2011), the decline in demand for currency forwards (especially from shipbuilders, due to a smaller order book in the post-crisis period) has also contributed to stemming the won-dollar nominal exchange rate appreciation.
}

2011 due to the strong increase in debt portfolio inflows, which reached record levels (IMF, 2011a). The impact of this measure on portfolio inflows is likely to be marginal, however, for two reasons. First, foreign corporations and non-resident investors based in countries that have double taxation treaties with the Republic of Korea are exempt, and the Republic of Korea has this kind of treaty with more than 70 countries. Second, this tax does not affect equity portfolio flows, which have also increased significantly since 2009 (Pradhan and others, 2011).

\section{Brazil}

The Brazilian Government responded to the 1999 currency crisis with the adoption of a new set of economic policies based on an inflation target and a managed (or dirty) floating exchange rate. This change in the macroeconomic regime was accompanied by a process of financial opening that began in 1990 and gained momentum in January 2000, when Resolution no. 2689 from the National Monetary Council (Conselho Monetário Nacional, or CMN) allowed the unrestricted access of non-resident (that is, foreign) investors to all segments of the domestic financial market, including the derivatives market. Moreover, in 2005, residents' capital exports were fully liberalized. The Brazilian economy thus became fully open to capital inflows and outflows.

In this context of high capital mobility, the postglobal-crisis scenario - combined with domestic factors (primarily the resumption of economic growth and very high interest rates, by international standards, until recently) _ resulted in large capital inflows and strong appreciation pressures between 2009 and mid-2011 (see figure 2 and table 3). ${ }^{8}$ Two specific features of the Brazilian economy (related to macroeconomic and institutional factors) reinforced the economic policy dilemmas faced by Brazilian monetary authorities in terms of macroeconomic management and financial regulation in the post-crisis context.

\footnotetext{
${ }^{8}$ Brazil became the main destination for capital flows in Latin America in this period (IMF, 2011a).
} 
FIGURE 2

Brazil: interest rate differential and nominal exchange rate ${ }^{a}$ (Percentages and reais per dollar)

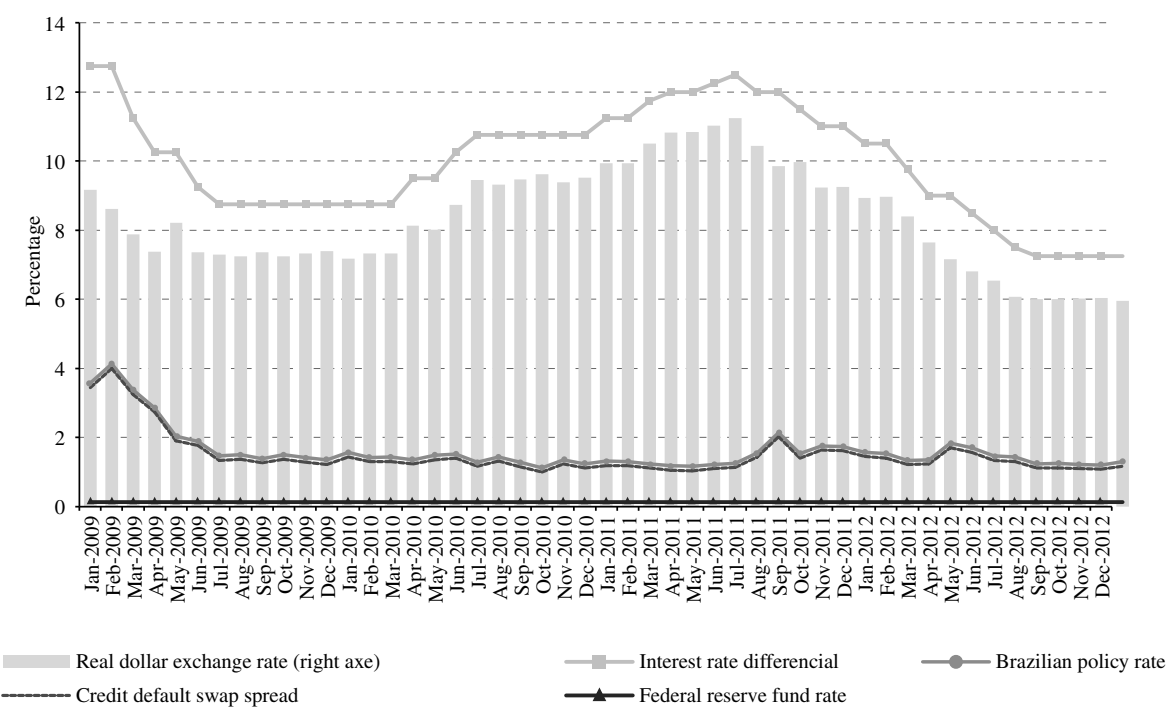

Source: Prepared by the authors, on the basis of information from the Central Bank of Brazil.

a Brazilian policy rate plus Brazil risk minus the federal funds rate.

TABLE 3

Brazil and Republic of Korea: selected macroeconomic data

\begin{tabular}{|c|c|c|c|c|c|c|c|c|}
\hline \multirow{2}{*}{ Year } & \multicolumn{2}{|c|}{$\begin{array}{c}\text { Policy rate } \\
\text { (percentages) }\end{array}$} & \multicolumn{2}{|c|}{$\begin{array}{c}\text { FX reserves } \\
\text { (billions of dollars) }\end{array}$} & \multicolumn{2}{|c|}{$\begin{array}{c}\text { Inflation } \\
\text { (percentages) }\end{array}$} & \multicolumn{2}{|c|}{$\begin{array}{c}\text { Fiscal result (nominal and } \\
\text { percentages of GNP) }\end{array}$} \\
\hline & Brazil & $\begin{array}{l}\text { Republic } \\
\text { of Korea }\end{array}$ & Brazil & $\begin{array}{l}\text { Republic } \\
\text { of Korea }\end{array}$ & Brazil & $\begin{array}{l}\text { Republic } \\
\text { of Korea }\end{array}$ & Brazil & $\begin{array}{l}\text { Republic } \\
\text { of Korea }\end{array}$ \\
\hline 2003 & 23.55 & 3.96 & 48844 & 154509 & 17.05 & 3.5 & -5.23 & 0.47 \\
\hline 2004 & 16.38 & 3.6 & 52458 & 198175 & 6.29 & 3.6 & -2.9 & 2.72 \\
\hline 2005 & 19.14 & 3.33 & 53216 & 209968 & 5.77 & 2.8 & -3.58 & 3.38 \\
\hline 2006 & 15.32 & 4.23 & 85148 & 238388 & 3.27 & 2.2 & -3.63 & 3.92 \\
\hline 2007 & 12.05 & 4.73 & 179431 & 261771 & 4.08 & 2.5 & -2.80 & 4.65 \\
\hline 2008 & 12.44 & 4.73 & 192842 & 200479 & 6.57 & 4.7 & -2.0 & 2.96 \\
\hline 2009 & 10.16 & 2.04 & 231888 & 265202 & 5.06 & 2.8 & -3.3 & -1.14 \\
\hline 2010 & 9.89 & 2.17 & 280570 & 286926 & 5.11 & 2.9 & -2.5 & -0.04 \\
\hline 2011 & 11.76 & 3.1 & 343384 & 298233 & 6.6 & 4.0 & n.a. & n.a. \\
\hline
\end{tabular}

Source: Prepared by the authors, on the basis of Oxford Economics [online] http://www.oxfordeconomics.com/; International Monetary Fund (IMF), International Financial Statistics; and statistical information from the respective countries.

As for the macroeconomic factor, Brazil's reserve accumulation strategy faces two important constraints: a significant amount of public debt concentrated in short-term maturities and a very large differential between internal and external interest rates (stemming from the high domestic policy rate).$^{9}$ These constraints made the cost of sterilization operations excessively high, reducing the central bank's

\footnotetext{
${ }^{9}$ This factor is not the focus of the paper and is therefore not described in detail here.
} 
policy space for exchange rate management (Prates, Cunha and Lélis, 2009a).

With regard to the institutional factor, which is the focus of this paper, both before and after the global financial crisis, the FX derivatives market has played a central role in the path of the Brazilian currency, the real, which has predominantly followed an appreciation trend. ${ }^{10}$ This has undermined the monetary authority's capacity to influence the exchange rate (based on conventional exchange rate interventions, such as intervention in the spot currency market) and the efficacy of capital controls and prudential financial regulations in stemming currency appreciation.

This central role of the FX derivatives market derives from the much higher number of trades and turnover of the FX futures market in comparison with the FX spot market, which, in turn, makes the FX futures market deeper and more liquid than the spot market. In this setting, FX futures operations have a key influence in the real-dollar exchange rate trend, as many studies point out (Farhi, 2010; Ventura and García, 2009; Prates, Cunha and Lélis 2009a; Kaltenbrunner, 2010; Chamon and Garcia, 2013). The most important determinant of the higher liquidity and depth of the FX futures market relative to the spot market is the prohibition of foreign currency accounts (bank deposits), with only a few exceptions. ${ }^{11}$ In other words, if we follow the concept of financial openness proposed by Akyüz (1993), the internal convertibility of the real is very limited, as almost all transactions have to be settled in the domestic currency. On the other hand, the Brazilian currency has a fully external convertibility, as capital inflows and outflows have been totally liberalized since 2005 .

This distinctive feature of the Brazilian currency is associated with the high inflation in the 1980s and the first half of the 1990s, which was marked by widespread indexation, especially in the financial sector. Indexation prevented the dollarization of domestic financial operations and the disintermediation of the banking process. Consequently, the financial sector engaged in sophisticated trading operations. Financial sophistication was further facilitated by the dominance of large

\footnotetext{
10 The Brazilian real was the second most traded currency worldwide in organized derivatives markets in 2010, while the financial volume of FX derivatives traded in onshore оTC markets was low (US\$ 18 billion in April 2010) relative to other emerging markets, such as the Republic of Korea (Avdjiev, Upper and Vause, 2010).

11 According to chapter 14 of the "International Capital and Foreign Exchange Market Regulation” (вСв, 2013), Fx bank accounts are allowed only for embassies, multilateral institutions and insurance companies that deal with foreign trade. However, their use is very limited.
}

domestic and foreign banks. Another institutional trait of the Brazilian financial system, also linked with the particular nature of the country's inflationary process, is the existence of a developed derivatives exchange since the 1980s (namely, the BM\&F), where FX futures contracts are traded. ${ }^{12}$

The limited internal convertibility of the real is the main determinant of the features that set the FX spot and derivatives markets apart from those of the Republic of Korea, as well as other Latin American emerging economies, such as Mexico, Chile and Colombia. In terms of the FX spot market, residents and non-residents are not allowed to have FX accounts; they cannot hold spot FX positions. Therefore, most spot FX transactions are settled by transfers of funds between FX accounts abroad. ${ }^{13}$ Therefore, they do not result in currency flows, but have an impact on non-residents' and residents' asset and liability positions held abroad. Furthermore, all FX transactions must be recorded under an FX contract. Only a few banks authorized by the Central Bank of Brazil to have FX portfolios can hold FX spot positions, as they have access to short-term external credit lines in the international interbank market (called "clean lines"). However, changes in these credit lines are not recorded under an FX contract since they only affect banks' overseas assets and liabilities.

In terms of the FX derivatives market (futures and отC), the limited internal convertibility of the real also underlies its non-deliverable nature. That is, gains or losses in this market are settled in domestic rather than the foreign currency, which is normally the case in other countries. Precisely because these operations are settled in real, any agent can hold positions in the FX futures market as long as they fulfil minimum standards required by the Brazilian exchange (Ventura and García, 2009; Kaltenbrunner, 2010). In the case of FX futures contracts, the main agents are resident banks (whether Brazilian or foreign-owned), resident institutional investors, nonfinancial resident companies and non-resident investors (who have had unrestricted access to the derivatives market since January 2000). During periods of low risk aversion both before the global financial crisis (2003 to mid-2008) and after it (mainly from mid-2009 to mid-2011), these investors (primarily hedge funds) have been the most important non-bank investor group in the Brazilian FX

\footnotetext{
12 On 25 March 2008, the BM\&F merged with BOVESPA, the main Brazilian stock exchange.

13 The exception is the buying and selling of foreign currencies related to international travels. In this case, physical flows are allowed (вСв, 2013).
} 
futures market, fostering a real appreciation trend through the derivatives carry trade. This is a different kind of currency speculation strategy from the canonical mode of carry trade through spot market operations - that is, borrowing low-interest-rate currencies and lending high-interest-rate currencies (Burnside and others, 2006; Gagnon and Chaboud, 2007; Kaltenbrunner, 2010). In derivatives markets, the carry trade expresses itself as a bet that results in a short position in the funding currency and a long position in the target currency (Gagnon and Chaboud, 2007).

As mentioned, the Brazilian macroeconomic environment is characterized by a dirty floating regime adopted in January 1999 and one of the largest interest rate differentials of the emerging economies (Prates, Cunha and Lélis, 2009a, see figure 2). This has led foreign investors to make one-way bets on the appreciation of the Brazilian currency through short positions in the FX futures market, selling United States dollars and buying reais. ${ }^{14}$ The result is downward pressure on the dollar price and thus upward pressure on the real price in the futures market (Farhi, 2010). Furthermore, the income tax on the yields of government bonds owned by foreign investors, which was in place through February 2006, also increased the advantages of the derivatives carry trade relative to the traditional carry trade.

The derivatives carry trade turns out to be even more attractive in Brazil due to the non-deliverable characteristic of the FX derivatives market. Foreign and domestic agents can engage in the derivatives carry trade without disbursing even a single United States dollar. Until October 2010, this carry trade strategy could also be executed without the expenditure of a single real because investors could meet their margin requirements in reais via domestic borrowed securities or guarantees from the resident banks. Despite the predominance of foreign investors in the derivatives carry trade, profitseeking domestic agents such as institutional investors and companies have also participated in this segment of the financial market.

Moreover, the outstanding performance of the reais futures market has contributed to increased trading of the Brazilian currency on offshore оTC markets through non-deliverable forward contracts (NDFS). The existence of a deep futures market has made it possible

\footnotetext{
${ }^{14}$ It is possible to profit from the appreciation of the Brazilian real and the positive interest rate differential via onshore derivatives traded at BM\&FBOVESPA. The most common trades are shorting the United States dollar futures contract, shorting contracts on the onshore dollar rate or shorting the onshore dollar rate, combined with the ongoing long on the domestic interest rate futures (DI x Pre) (Ventura and García, 2011).
}

for foreign banks with branches in Brazil to sell reais offshore and simultaneously hedge their real exposure in the onshore futures market (Kaltenbrunner, 2010). The growth of the NDF market for the Brazilian real has, in turn, enhanced the liquidity and depth of the Brazilian futures market even further. Consequently, some international investors began to use reais futures contracts as a proxy for other emerging currencies' derivatives, which have been highly correlated with the Brazilian real but do not have deep and liquid derivatives markets, such as the Turkish lira and the South African rand. This practice further increased the trading of reais futures contracts.

The wide range of participants ensures greater trade volume and turnover in the FX futures market relative to the FX spot market. As Ventura and García (2009) point out, given the higher liquidity of the FX futures market, banks with FX portfolios have chosen to transfer operations typical of the spot FX market to the FX futures market, increasing their trades with FX futures. As these authors argue, the first dollar futures contract (30 days for next settlement) has become the locus of formation for the real-dollar exchange rate, based on its high liquidity. The spot exchange rate results from arbitrage between the futures and spot exchange rates carried out by banks with FX portfolios. In general, these agents are in a position opposite that of non-bank investors (among which foreign investors were prominent between 2009 and mid-2011) in the FX futures market: they hold a long position in dollars and short in reais, which means they buy dollars in this market and sell them in the spot market. With this strategy, banks have earned arbitrage profits and, at the same time, generated pressure on the dollar spot price, which has meant a drop in the real-dollar spot exchange rate and an appreciation of the Brazilian currency. Because only banks can hold FX positions in the FX spot market in Brazil, they have played a central role in conveying appreciation pressure through the carry trade in the futures market to the real-dollar spot exchange rate. ${ }^{15}$ At the same time, this key role of FX futures in the real-dollar exchange rate dynamics does not mean that spot FX transactions do not also have an influence. Arbitrage between the futures and spot rates only works if there is liquidity in the spot market, which depends on actual FX inflows and outflows.

\footnotetext{
15 The role of FX derivatives in the current exchange rate dynamics of advanced economies' currencies has been pointed out by Burnside and others (2006) and Klitgaard (2004). However, the theoretical analysis of the key influence of these instruments in exchange rate dynamics is far from consolidated.
} 
The main goal of the capital controls, prudential financial regulations and FX derivatives regulations implemented in Brazil since October 2009 is to curb the appreciation of the real. The day after the first control was announced, the Finance Minister, Guido Mantega, stated that "We want to prevent an excessive appreciation of the real. When the real appreciates, it makes our exports more expensive and our imports cheaper, and we already have an expressive increase in imports while the exports are not growing as they should" (cited in Chamon and Garcia, 2013, p. 7). Each measure was publicly announced by Guido Mantega and throughout the course of his speeches on their use, he repeatedly referred to the capital flows as a "tsunami" caused by lax monetary policy in the United States of America and beyond. He said the financial transactions tax (IOF) and related measures were Brazil's only defence against this tsunami and the "currency war" thrust upon them by the United States and China (Gallagher, 2014).

Thus, specific features of the Brazilian currency market presented Brazilian policymakers with greater challenges than those faced by their counterparts in the Republic of Korea. On the one hand, because FX derivatives are non-deliverable, they could simulate the impact of capital flows on the exchange rate without any actual foreign currency flows, thereby lowering the efficacy of capital controls. On the other hand, given the predominance of FX futures, prudential financial regulation has also proved insufficient to reach FX derivatives operations, as it does not encompass non-resident investors and non-bank resident agents. Nevertheless, this regulation does reach banks' short dollar positions in the FX spot market, which are outside the scope of capital controls that apply only to FX flows recorded in FX contracts.

The Brazilian regulatory authorities recognize these constraints. Since October 2010, they have implemented, along with capital controls and prudential financial regulations, FX derivatives regulations that apply to the FX derivatives operations of all agents, be they residents or non-residents, financial or non-financial actors.

In October 2010, along with strengthening a pricebased capital control on portfolio investment (a tax on capital inflows called a financial transactions tax (IOF)), the Brazilian Government launched the first FX derivatives regulation: IOF on margin requirements for FX derivatives transactions was increased from $0.38 \%$ to $6.0 \%$, and some loopholes for IOF on margin requirements were closed (see table 4). However, the first rounds of capital controls and FX derivatives regulation have clearly not halted the currency appreciation. Private agents found loopholes to circumvent these controls, and the FX derivatives regulations were not sufficient to stem the derivatives carry trade, given the latter's high degree of leverage (see figure 3). In fact, IOF on portfolio inflows only encouraged the build-up of long real/short dollar positions on the onshore derivatives market; that is, it fostered the derivatives carry trade supported by resident banks with FX portfolios that assumed the position opposite that of non-resident investors in the derivatives market (short real/long dollar positions). Since these banks have to comply with prudential rules regarding their FX positions, they increased their short dollar positions in the spot currency market with the aim of reducing or eliminating the currency risk (IMF, 2011a).

TABLE 4

Brazil: financial regulation toolkit

\begin{tabular}{|c|c|c|c|}
\hline Date & Number and kind & Tighten or loosen & Measure \\
\hline Oct. 2009 & 1 st CC & Tighten & $\begin{array}{l}\text { - The Ministry of Finance implemented a } 2 \% \text { financial transaction tax (IOF) } \\
\text { on non-resident equity and fixed-income portfolio inflows. }\end{array}$ \\
\hline Oct. 2010 & 2nd CC & Tighten & $\begin{array}{l}\text { - IOF increased from } 2 \% \text { to } 4 \% \text { for fixed-income portfolio investments } \\
\text { and equity funds. } \\
\text { - IOF increased to } 6 \% \text { for fixed-income investments. } \\
\text { - Limitations were also introduced on the ability of foreign investors to shift } \\
\text { investment from equity to fixed-income investment. }\end{array}$ \\
\hline Oct. 2010 & 1st FXDR & Tighten & $\begin{array}{l}\text { - IOF on margin requirements on FX derivatives transactions increased } \\
\text { from } 0.38 \% \text { to } 6 \% \text {. } \\
\text { - Loopholes for IOF on margin requirements were closed: foreign investors in the } \\
\text { futures markets were no longer allowed to meet their margin requirements via } \\
\text { locally borrowed securities or guarantees from local banks, which allowed them } \\
\text { to avoid payment of the tax. }\end{array}$ \\
\hline Jan. 2011 & 1st PR & Tighten & $\begin{array}{l}\text { - Non-interest reserve requirement equivalent to } 60 \% \text { of banks' short dollar } \\
\text { positions in the FX spot market that exceed US\$ } 3 \text { billion or their capital base, } \\
\text { whichever is smaller (to be implemented over } 90 \text { days). }\end{array}$ \\
\hline
\end{tabular}


Table 4 (concluded)

\begin{tabular}{|c|c|c|c|}
\hline Mar. 2011 & 3rd cC & Tighten & $\begin{array}{l}\text { - IOF on new foreign loans (banking loans and securities issued abroad) with } \\
\text { maturities of up to } 1 \text { year increased to } 6 \% \text {. Companies and banks previously } \\
\text { only paid a } 5.38 \% \text { IOF on loans up to } 90 \text { days. }\end{array}$ \\
\hline Apr. 2011 & 4th CC & Tighten & $\begin{array}{l}\text { - } 6 \% \text { IOF extended for the renewal of foreign loans with maturities of up to } 1 \text { year. } \\
6 \% \text { IOF extended for both new and renewed foreign loans with maturities } \\
\text { of up to } 2 \text { years. }\end{array}$ \\
\hline July 2011 & 2nd PR & Tighten & $\begin{array}{l}\text { - The non-interest reserve requirement became mandatory for amounts over } \\
\text { US\$ } 1 \text { billion or their capital base (whichever is smaller). }\end{array}$ \\
\hline July 2011 & 2nd FXDR & Tighten & $\begin{array}{l}\text { - Excessive long positions on Brazilian real off all agents pay a financial tax } \\
\text { of } 1 \% \text {. This tax can be increased up to } 25 \% \text {. }\end{array}$ \\
\hline Dec. 2011 & 5th CC & Loosen & $\begin{array}{l}\text { - IOF on equity and fixed-income (linked with infrastructure projects) portfolio } \\
\text { inflows reduced to } 0 \% \text {. }\end{array}$ \\
\hline Mar. 2012 & 6th CC & Tighten & $\begin{array}{l}\text { - } 6 \% \text { IOF extended for both new and renewed foreign loans with maturities } \\
\text { of up to } 3 \text { years; some days, extended again for both new and renewed foreign } \\
\text { loans with maturities of up to } 5 \text { years. } \\
\text { Export advanced payment transactions with maturities of more than } \\
\text { a year prohibited. }\end{array}$ \\
\hline Mar. 2012 & 3rd FXDR & Loosen & $\begin{array}{l}\text { - Exporters hedge operations (up to } 1.2 \text { times the exports of the previous year) } \\
\text { exempted from IoF. }\end{array}$ \\
\hline June 2012 & 7th CC & Loosen & $\begin{array}{l}\text { - } 6 \% \text { IOF only for new and renewed foreign loans with maturities of up to } 2 \text { years } \\
\text { (namely, the changes adopted in March were reversed). }\end{array}$ \\
\hline Dec. 2012 & 8th CC & Loosen & $\begin{array}{l}\text { - } 6 \% \text { IOF only for new and renewed foreign loans with maturities of up to } 1 \text { year. } \\
\text { - Export advanced payment transactions maturity extended from } 1 \text { to } 5 \text { years. }\end{array}$ \\
\hline
\end{tabular}

Source: Prepared by the authors, on the basis of information from the Central Bank of Brazil [online] http://www.bcb.gov.br/pt-br/paginas/ default.aspx; and the Ministry of Finance [online] http://www.fazenda.gov.br/.

Note: CC: Capital control; PR: Prudential regulation; FXDR: Foreign exchange derivatives regulation; IOF: Financial transactions tax.

FIGURE 3

Brazil: nominal exchange rate and the application of tighter regulations

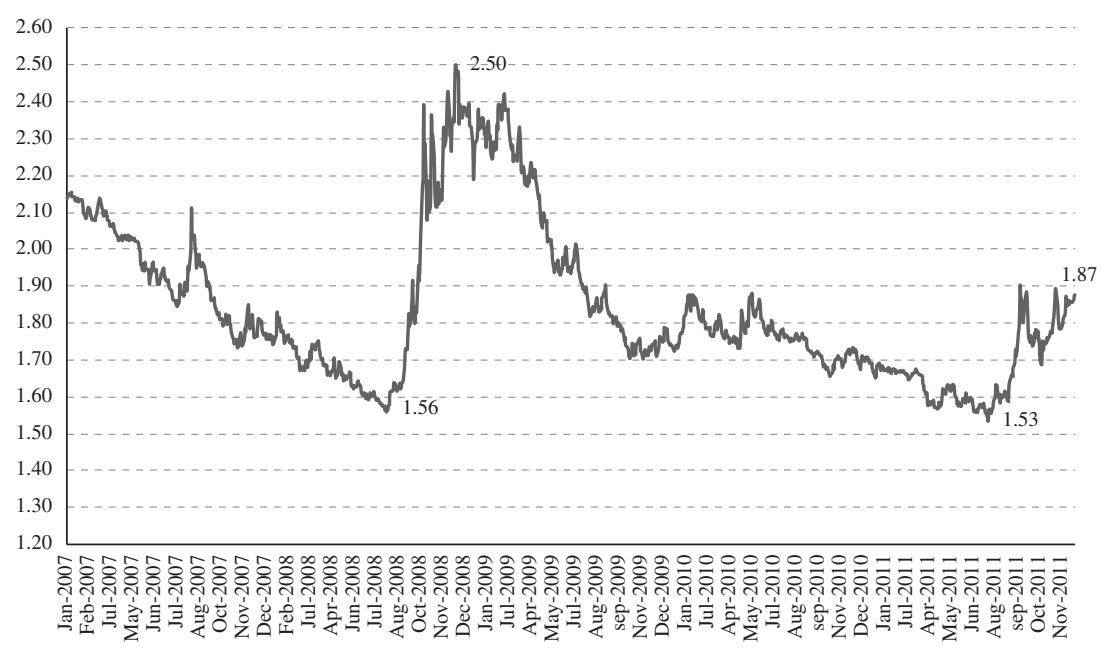

Source: Prepared by the authors, on the basis of information from the Central Bank of Brazil. 
To close this loophole, the Central Bank of Brazil imposed a non-interest reserve requirement (a prudential financial regulation) on these positions in January 2010. Nevertheless, by switching to short-term foreign borrowing, banks and companies were able to find another channel to circumvent regulations. In response, the Government imposed IOF on short-term foreign borrowing in March 2011, but private agents were able to make longerterm loans, given excess liquidity and the search for yield on the international financial market. In April 2011, the Government subsequently extended IOF to these loans.

The currency continued to appreciate (see figure 3 ). In July 2011, the Government tightened the prudential financial regulation adopted in January and launched a broader set of FX derivatives regulations, including a financial tax of $1.0 \%$ on excessively long net positions on the real in the FX derivatives market. Because this tax is calculated on the notional value of the FX derivatives operations, it had a major impact on the derivatives carry trade and was comparable to IOF on the margin requirement already in force. The adoption of this tax was possible because at the same time, the National Monetary Council (CMN) was made responsible for regulating the derivatives market, and new rules regarding the recording of FX derivatives were adopted. CMN comprises the Central Bank Governor, the Minister of Finance, and the Minister of Planning, Budget and Management (see [online] www.bcb.gov.br/?cmn). These institutions could then easily coordinate their efforts to contain appreciation pressures stemming from this market segment.

These measures had some effects, at least in the short term. Before long, however, important changes took place both in the external environment and in domestic monetary policy that also influenced the exchange rate path. First, foreign agents' risk aversion, as measured by the VIX volatility index, increased amidst the worsening of the euro crisis (see figure 4). Second, the regulatory shift was embedded in a major policy rate cut from August 2011 onward (see figure 2). Still, although VIX had begun to rise in the first week of July, the Brazilian currency only began depreciating after the launch of the new FX regulations, but before the policy rate reductions in August (see figures 2, 3, and 4).

FIGURE 4

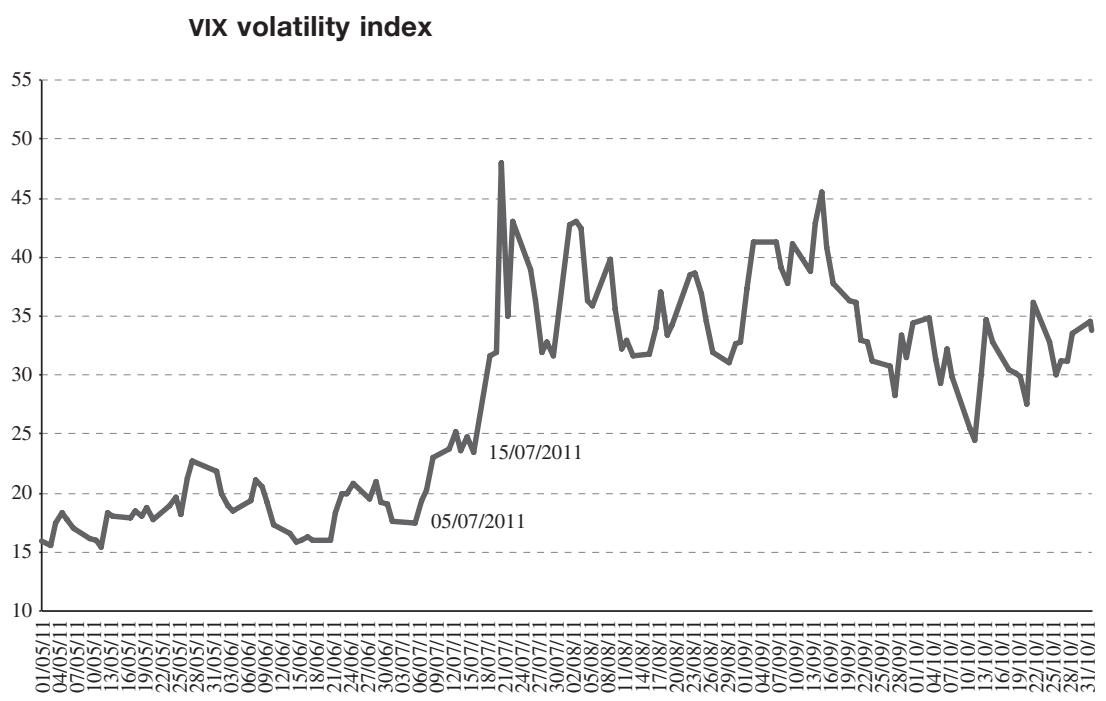

Source: Prepared by the authors, on the basis of information from the Chicago Board Options Exchange.

Some empirical studies suggest that the Brazilian regulatory toolkit was successful in curbing the currency appreciation trend. For instance, Chamon and Garcia (2013) stress that the measures adopted to stem the currency appreciation may have amplified the effects of the policy rate drop between August 2011 and October 2012 on the real-dollar exchange rate. Baumann and Gallagher (2012) find that the regulation adopted by the Brazilian policymakers between October 2009 and December 2012 was associated with a shift from short- 
term to longer-term inflows, had a lasting impact on the level and volatility of the exchange rate and modestly increased the autonomy of Brazilian monetary policy. On the other hand, Klein (2012) concludes that the Brazilian
IOF was an episodic control on capital inflows that did not temper the appreciation of the Brazilian currency; however, the period covered in his study ends in 2010, before the adoption of broader FX derivatives regulation.

FIGURE 5

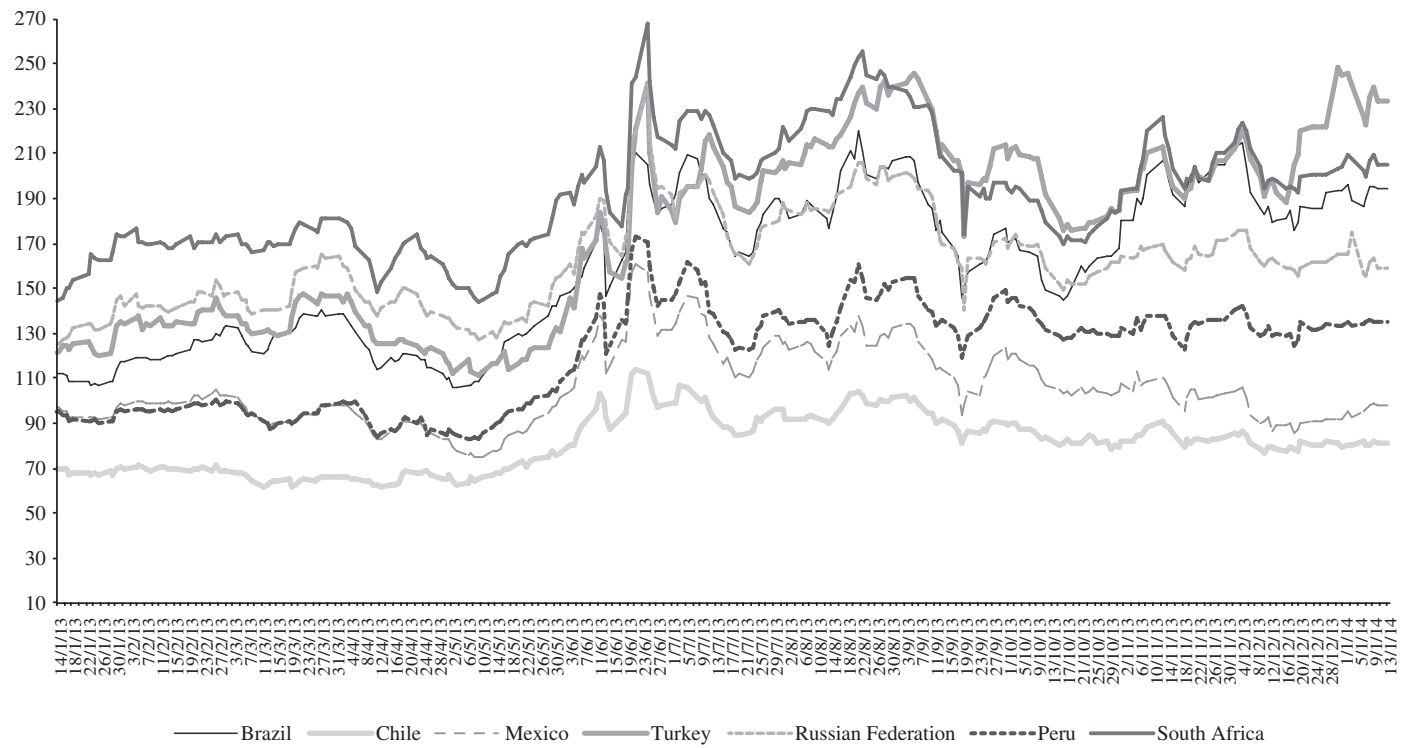

Source: Prepared by the authors, on the basis of information from Bloomberg.

\section{IV}

\section{Conclusions}

As emerging markets with open financial accounts and sophisticated FX derivatives markets, the case studies of Brazil and the Republic of Korea exemplify that country-specific factors have to be considered when designing the financial regulatory toolkit aimed at curbing foreign and domestic agents' speculative strategies in the search for yield. Three insights emerge from our comparative analysis.

First, the necessary breadth of financial regulation depends on the financial actors involved and the type of financial contract. In Brazil, it was necessary to implement a third type of regulation, which we call FX derivatives regulation, because the main locus of FX operations is the organized derivatives market, where resident and non-resident banks and non-bank financial agents are involved. Consequently, prudential financial regulation is not sufficient. The Brazilian case also serves as an example in which capital controls are insufficient to curb FX derivatives, because both resident and non-resident operations are denominated in foreign currency, but liquidated in domestic currency, and the effect of foreign investors' portfolio decisions on the exchange rate may be uncoupled from the volume of international capital flows. Similarly, in the Republic of Korea, prudential financial regulation has been able to reach FX derivatives operations, because they are mostly carried out on OTC markets - where banks perform the role of counterparty in all transactions - and the operations are settled in United States dollars. Thus, prudential regulation is able to cover all operations. 
Second, institutional specifications in a strict sense are relevant. It is important to have effective domestic institutions and jurisdictions able to formulate and implement regulations. Unlike many emerging economies, Brazil has an institutional framework that allows financial authorities to act quickly and at their discretion to impose regulations on capital flows and FX derivatives. The framework is based on three institutional tools: (i) domestic norms on FX transactions allow for the implementation of capital controls and FX derivatives regulations at any time; (ii) Brazil's finance ministry has jurisdiction over all tax policy, including any taxes on cross-border finance; and (iii) all monetary, credit and exchange rate policies in Brazil must be agreed on by consensus by CMN, a body that includes representatives of the Central Bank and the Finance Ministry. Thus, monetary and exchange rate policies and financial regulation can be properly coordinated, which seems to be highly relevant in determining their potential effectiveness (see Prates and Fritz, 2014).

Third, countries should not limit their own policy space through multilateral or bilateral agreements; rather these agreements should leave manoeuvring room for domestic policies. Brazil has been able to launch broad capital controls and FX derivatives regulations because, since the 1990s, the Government has been careful to avoid any commitments under the General Agreement on Trade in Services (GATS), or to sign any bilateral investment treaties or free trade agreements that could reduce the country's policy space to implement these regulations at any moment (Paula and Prates, 2013). While most treaties that liberalize trade in services employ a "positive list" approach with respect to trade in financial services, capital controls and FX regulations could become inconsistent with treaty obligations if they intervene in cross-border movements of capital related to such services. The Republic of Korea, as an OECD member State, is much more restricted in regulating transnational financial transactions, and it also has double taxation treaties with most of its economic partner countries, so taxes on capital flows do not apply. Hence, it was mainly the dominant presence of resident banks in international capital flow transactions that enabled the Republic of Korea authorities to regulate the relevant operations.

\section{Bibliography}

Akyüz, Y. (2011), "Capital flows to developing countries in a historical perspective. Will the current boom end with a bust and how?", Research Paper, No. 37, South Centre.

(1993), "Financial liberalization: the key issues", UNCTAD Discussion Papers, No. 56, Geneva, United Nations Conference on Trade and Development (UNCTAD).

Ariyoshi, A. and others (2000), "Capital controls. Country experiences with their use and liberalization", IMF Occasional Papers, No. 190, Washington, D.C., International Monetary Fund.

Avdjiev, S., Ch. Upper and N. Vause (2010), "Highlights of international banking and financial market activity", BIS Quarterly Review, Basel, Bank for International Settlements, December.

Baba, Ch. and A. Kokenyne (2011), "Effectiveness of capital controls in selected emerging markets in the 2000s", IMF Working Paper, No. WP/11/281, Washington, D.C., International Monetary Fund.

Baumann, B.A. and K.P. Gallagher (2013), "Post-crisis capital account regulation in South Korea and South Africa", PERI Working Paper, No. 320, Amherst, Political Economy Research Institute. (2012), "Navigating capital flows in Brazil and Chile", Initiative for Policy Dialogue Working Paper Series [online] http://policydialogue.org/files/publications/Working_PaperNavigating_Capital_Flows_in_Brazil_and_Chile.pdf.

ВСв (Central Bank of Brazil) (2013), "International Capital and Foreign Exchange Market Regulation-RMCCI" [online] http://www.bcb. gov.br/?RMCCINORMS.

Bhagwati, J. (1998), "Why Free Capital Mobility May be Hazardous to Your Health: Lessons from the Latest Financial Crisis" [online] http://academiccommons.columbia.edu/catalog/ac\%3A123599.

BIS (Bank for International Settlements) (2010), Triennial Central Bank Survey. Report on Global Foreign Exchange Market Activity in 2010, Basel [online] http://www.bis.org/publ/rpFxf10t.pdf.

Blanchard, O., G. Dell'Ariccia and P. Mauro (2010), "Rethinking macroeconomic policy", IMF Staff Position Note, No. SPN/10/03, Washington, D.C., International Monetary Fund.
Bruno, V. and H.S. Shin (2013), "Assessing macroprudential policies: case of Korea", NBER Working Paper, No. 19084, Cambridge, Massachusetts, National Bureau of Economic Research.

Burnside, C. and others (2006), "The returns to currency speculation", NBER Working Paper, No. 12489, Cambridge, Massachusetts, National Bureau of Economic Research.

Canuto, O. and M. Giugale (eds.) (2010), The Day After Tomorrow. A Handbook on the Future of Economic Policy in the Developing World, Washington, D.C., World Bank.

Canuto, O. and D. Leipziger (eds.) (2012), Ascent after Decline: Regrowing Global Economies after the Great Recession, Washington, D.C., World Bank.

Chamon, M. and M. Garcia (2013), "Capital controls in Brazil: effective?" [online] https://www.imf.org/external/np/res/seminars/ 2014/arc/pdf/chamon_garcia.pdf.

Cordero, J. and J.A. Montecino (2010), Capital Controls and Monetary Policy in Developing Countries, Washington, D.C., Centre for Economic Policy Research.

Dell'Ariccia, G. and others (2008), "Reaping the benefits of financial globalization", IMF Occasional Paper, No. 264, Washington, D.C., International Monetary Fund.

Dodd, R. (2009), "Exotic derivatives losses in emerging markets: questions of suitability, concerns for stability", IMF Working Paper, No. WP/09, Washington, D.C., International Monetary Fund.

Dooley, M. (1996), "A survey of literature on controls over international capital transactions", IMF Staff Papers, vol. 43, No. 4, Washington, D.C., Palgrave Macmillan.

Eichengreen, B. and others (2011), Rethinking Central Banking. Committee on International Economic Policy and Reform, Washington, D.C., Brookings.

Epstein, G., I. Grabel and K.S. Jomo (2004), “Capital management techniques in developing countries: an assessment of experiences from the 1990s and lessons for the future", G-24 Discussion Paper, No. 27, Geneva, United Nations Conference on Trade and Development. 
Farhi, M. (2010), "Os impactos dos derivativos no Brasil", Sistema financeiro e desenvolvimento no Brasil, L.C. Marcolino and R. Carneiro (eds.), São Paulo, Atitude.

Farhi, E. and I. Werning (2012), "Dealing with the trilemma: optimal capital controls with fixed exchange rates", NBER Working Paper, No. 18199, Cambridge, Massachusetts, National Bureau of Economic Research.

Fettig, D. (1996), "Interview with James Tobin", The Region, Federal Reserve Bank of Minneapolis, 1 December [online] http://bit. ly/VpqsgL.

Forbes, K. and others (2012), "Bubble thy neighbor: portfolio effects and externalities from capital controls", NBER Working Paper, No. 18052, Cambridge, Massachusetts, National Bureau of Economic Research.

Fritz, B. and D. Magalhães Prates (2014), "The new IMF approach to capital account management and its blind spots: lessons from Brazil and South Korea", International Review of Applied Economics, vol. 28, No. 2, Taylor \& Francis.

Gagnon, J. and A.P. Chaboud (2007), "What can the data tell us about carry trades in Japanese Yen?", FRB International Finance Discussion Papers, No. 899, Washington, D.C., Federal Reserve Board.

Gallagher, K. (2014), Countervailing Monetary Power: Emerging Markets and the Re-Regulation of Cross-Border Finance, Ithaca, Cornell University Press.

(2012), "The IMF's new view on financial globalization: a critical assessment", Issues in Brief, No. 2, Boston, Frederick S. Pardee Center for the Study of the Longer-Range Future.

Gallagher, K., S. Griffith-Jones and J.A. Ocampo (eds.) (2012), Regulating Global Capital Flows for Long-Run Development, Boston, Frederick S. Pardee Center for the Study of the LongerRange Future.

Hennings, K. and F.A. Rocha (2013), "Evolution of Capital Flows to the Brazilian Economy after 2008", Central Bank of Brazil, unpublished.

Herr, H. and J. Priewe (2006), "Capital Account Regimes and Monetary Policy in Developing Countries. Liberalization with Regulation", Berlin, unpublished.

Huh, I., J. An and D. Yang (2013), "The effect of Korea's macroprudential measures", World Economy Update, vol. 3, No. 3, Seoul, Korea Institute for International Economic Policy.

IMF (International Monetary Fund) (2012a), "Liberalizing capital flows and managing capital outflows", Public Information Notice, No. 12/42 [online] http://bit.ly/SLs06q.

(2012b), "The Liberalization and Management of Capital Flows: An Institutional View" [online] http://www.imf.org/ external/np/pp/eng/2012/111412.pdf.

(2011a), "Recent Experiences in Managing Capital Inflows. Cross-Cutting Themes and Possible Policy Framework" [online] http://bit.ly/QSqrVQ.

(2011b), "The Multilateral Aspects of Policies Affecting Capital Flows" [online] http://bit.ly/SRk4lr.

(2010), "The Fund's Role Regarding Cross-Border Capital Flows" [online] http://bit.ly/Z5fLH0.

(2005), The Evaluation of the IMF's Approach to Capital Account Liberalization [online] http://bit.ly/VuHjz5.

Jeanne, O. (2012), "Capital flow management", American Economic Review, vol. 102, No. 3, Nashville, Tennessee, American Economic Association.

Jeanne, O., A. Subramanian and J. Williamson (2012), Who Needs to Open the Capital Account?, Washington, D.C., Peterson Institute for International Economics.

Jinjarak, Y., I. Noy and H. Zheng (2013), "Capital controls in Brazil -Stemming a tide with a signal?", NBER Working Paper, No. 19205, Cambridge, Massachusetts, National Bureau of Economic Research.

Johnson, C. (2007), "Trading volume. Strong start to 2007 in most markets", Futures Industry Magazine, May-June.
Jong-Heon, L. (2008), "South Korean firms suffering cash crunch", UPI Asia, 18 November.

Jun, K. and I. Nam (2012), "South Korea tightens FX rules to temper won surge", The Wall Street Journal, 26 November.

Kaltenbrunner, A. (2010), "International Financialization and Depreciation: The Brazilian Real in the international financial crisis", Competition and Change, vol. 14, No. 3-4, sage.

Kaltenbrunner, A. and J.P. Painceira (2013), The Impossible Trinity on "Steroids": Inflation Targeting and Exchange Rate Management in Emerging Markets, Leeds University Business School.

Kim, S. and D. Yong Yang (2010), "Managing capital flows. The case of the Republic of Korea", Managing Capital Flows. The Search for a Framework, M. Kawai and M.B. Lamberte (eds.), Cheltenham, Edward Elgar/Asian Development Bank Institute.

Klein, M.W. (2012), "Capital Controls: Gates versus Walls", Brookings Papers on Economic Activity [online] http://www. brookings.edu/ /media/Projects/BPEA/Fall\%202012/2012b_ Klein.pdf.

Klitgaard, T. (2004), "Exchange rate changes and net positions of speculators in the futures market", Economic Policy Review, vol. 10, No. 1, New York, Federal Reserve Bank of New York, May.

Korinek, A. (2008), Regulating Capital Flows to Emerging Markets: an externality view, University of Maryland [online] http:// siteresources.worldbank.org/INTFR/Resources/Korinek CapitalFlows092908.pdf.

Kose, A. and others (2006), "Financial flobalization: a reappraisal", NBER Working Paper, No. 12484, Cambridge, Massachusetts, National Bureau for Economic Research.

Magud, N., C.M. Reinhart and K. Rogoff (2011), "Capital controls: myth and reality. A portfolio balance approach", NBER Working Paper, No. 16805, Cambridge, Massachusetts, National Bureau of Economic Research.

Mihaljek, D. and F. Packer (2010), "Derivatives in emerging markets", BIS Quarterly Review, Basel, Bank for International Settlements, December.

Mohan, R. (2012), "Capital account management: the need for a new consensus", Regulating Global Capital Flows for Long-Run Development, K. Gallagher and others (eds.), Boston, Frederick S. Pardee Center for the Study of the Longer-Range Future.

Mussa, M. and others (1998), "Capital account liberalization: theoretical and practical aspects", IMF Occasional Paper, No. 172, Washington, D.C., International Monetary Fund.

Neely, Ch. (1999), "An introduction to capital controls", Review, Federal Reserve Bank of Saint Louis, November-December.

Nogueira Batista Jr., P. (2012), "The IMF, capital account regulation, and emerging market economies", Regulating Global Capital Flows for Long-Run Development, K. Gallagher and others (eds.), Boston, Frederick S. Pardee Center for the Study of the Longer-Range Future.

Ocampo, J.A. (2012), "The case for and experience with capital account regulations", Regulating Global Capital Flows for Long-Run Development, K. Gallagher and others (eds.), Boston, Frederick S. Pardee Center for the Study of the LongerRange Future.

OECD (Organisation for Economic Cooperation and Development) (2009), "Code of Liberalization of Capital Movements and of Current Invisible Operations" [online] http://www. oecd.org/document/59/0,3343,en_2649_34887_1826559_ 1_1_1_1,00.html.

Ostry, J. and others (2011a), "Managing capital inflows: what tools to use?", IMF Staff Discussion Notes, No. 11/06, Washington, D.C., International Monetary Fund.

(2011b), "Capital controls: when and why?", IMF Economic Review, vol. 59, No. 3, Washington, D.C., Palgrave Macmillan. (2010), "Capital inflows. The role of controls", IMF Staff Position Note, No. 2010/04, Washington, D.C., International Monetary Fund. 
Paula, L.F. and D. Prates (2013), "Regulación de la cuenta de capital, tratados de comercio e inversión y espacio de políticas de Brasil", Regulación de la cuenta de capital y el sistema de comercio: un estudio de compatibilidad, K. Gallagher and L. Stanley (eds.), Boston, Frederick S. Pardee Center for the Study of the Longer-Range Future.

Pradhan, M. and others (2011), "Policy responses to capital flows in emerging markets", IMF Staff Discussion Notes, No. 11/10, Washington, D.C., International Monetary Fund.

Prates, D. and B. Fritz (2014), "Capital account regulation as part of the macroeconomic regime: comparing Brazil in the 1990s and 2000s", unpublished.

Prates, D. and M. Cintra (2010), "The emerging-market economies in the face of the global financial crisis", The Financial and Economic Crisis of 2008-2009 and Developing Countries (UNCTAD/GDS/MDP/2010/1), S. Dullien and others (eds.), Geneva, United Nations.

Prates, D., A. Cunha and M.T.C. Lélis (2009a), "Exchange-rate management in Brazil", CEPAL Review, No. 99 (LC/G.2418-P), Santiago, Economic Commission for Latin America and the Caribbean (ECLAC)

(2009b), "Os determinantes das taxas de câmbio nominal e real no Brasil no período 2003-2007", Ensaios sobre Economia Financeira, F. Ferreira and B. Meireles (orgs.), Rio de Janeiro, Brazilian Development Bank (BNDES)
Priewe, J. (2011), “Capital Account Management in Developing Countries", Geneva, preliminary version.

Rodrik, D. (2010), “The end of an era in finance?", Project Syndicate [online] http://bit.ly/XuxYxl.

(2008), "Second-best institutions", NBER Working Paper, No. 14050, Cambridge, Massachusetts, National Bureau of Economic Research.

(2006), "The social cost of foreign exchange reserves", International Economic Journal, vol. 20, No. 3, Taylor \& Francis.

Rogoff, K. and others (2004), "Effects of financial globalization on developing countries: some empirical evidence", IMF Occasional Papers, No. 220, Washington, D.C., International Monetary Fund.

Ventura, A. and M. García (2009), "Mercados futuro e à vista de câmbio no Brasil: o rabo balança o cachorro", Texto para Discussão, No. 563, Rio de Janeiro, Department of Economics, Catholic University of Rio de Janeiro.

Williamson, J. (2005), Curbing the Boom-Bust Cycle: Stabilizing Capital Flows to Emerging Markets, Washington, D.C., Peterson Institute.

Williamson, J., S. Griffith-Jones and R. Gottschalk (2003), "Should Capital Controls Have a Place in the Future International Monetary System?" [online] http://bit.ly/12h2wlK.

World Bank (2001), Financiamiento para el crecimiento económico. Opciones de política en un mundo volátil, Washington, D.C., Alfaomega. 